\title{
Synthetic Modifications of Lead Compounds as Antitrypanosomal Drugs
}

\author{
H. Cerecetto ${ }^{1}$, R. Di Maio ${ }^{1}$, G. Seoane ${ }^{1}$, A. Denicola ${ }^{2}$, G. Peluffo ${ }^{3}$ and C. Quijano ${ }^{2,3}$ \\ ${ }^{1}$ Cátedra de Química Orgánica, Facultad de Química \\ ${ }^{2}$ Departamento de Fisicoquímica Biológica, Facultad de Ciencias \\ ${ }^{3}$ Departamento de Bioquímica, Facultad de Medicina, Universidad de la República. General Flores \\ 2124, Montevideo, Uruguay
}

Abstract: Following our work in the synthesis of compounds with antichagasic activity, we describe new potential products in which the same "leader" compound was modulated.

\section{Introduction}

We have previously reported the synthesis and biological activity against Trypanosoma cruzi epimastigote forms in vitro and in vivo, of a series of semicarbazone derivatives of 5-nitrofurfural ("leader" compounds) [1,2].

\section{Experimental}

The synthesis of the new compounds is shown in the following scheme:<smiles>O=C/C=C/c1ccc([N+](=O)[O-])o1</smiles>

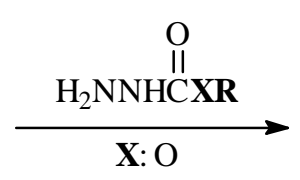

$\mathrm{NH}$

$\mathbf{R}:\left(\mathrm{CH}_{2}\right)_{\mathrm{n}} \mathrm{CH}_{3}, \mathrm{n}=2$ - 7

$\mathrm{CH}_{2} \mathrm{CH}_{2} \mathrm{OCH}_{3}$<smiles>[R]C(=O)NN=Cc1ccc([N+](=O)[O-])o1</smiles><smiles>[R]C(=O)NN=C/C=C/c1ccc([N+](=O)[O-])o1</smiles>

This compounds (I-IX), treated with Lawesson' reagent, produced the thiocarbonyl compounds.

\section{Results and Discussion}

The new compounds were identified by ${ }^{1} \mathrm{H}-\mathrm{NMR},{ }^{13} \mathrm{C}-\mathrm{NMR}, \mathrm{IR}, \mathrm{MS}$ and were tested in vitro against epimastigote forms of Trypanosoma cruzi. 
Acknowledgements: The authors thank PEDECIBA Química and RELAQ (Red Latinoamericana de Ciencia Química).

\section{References and Notes}

1. Cerecetto, H.; Di Maio, R.; Ibarruri, G.; Seoane, G.; Denicola, A.; Peluffo, G.; Quijano, C.; Paulino, M. Synthesis and anty-trypanosomal activity of novel 5-Nitro-2-furaldehyde and 5Nitrotiophene-2-carboxaldehyde semicarbazones derivatives, Il farmaco 1998, 53, 89-94.

2. Cerecetto, H.; Di Maio, R.; González, M.; Risso, M.; Sagrera, G.; Seoane, G.; Denicola, A.; Peluffo, G.; Quijano, C.; Basombrío, M.A.; Stoppani, A.O.M.; Paulino, M.; Olea-Azar, C. Synthesis and anty-trypanosomal evaluation of E-isomers of 5-nitro-2-furaldehyde and 5-Nitrotiophene-2carboxaldehyde semicarbazones. Eur. J. Med. Chem. (in press). 